\title{
Horses and the Aristocratic Lifestyle in Early Modern England: William Cavendish, First
}

Earl of Devonshire (1551-1626) and his Horses. By Peter Edwards. Woodbridge. The Boydell

Press, 2018. xv. + 256 pp. ISBN 978-1-78327-288-4. £75.00

With the activities of the Earl of Devonshire as its principal focus, this scholarly and deeplyresearched book sets out the many important functions horses had for aristocratic households in Elizabethan and Jacobean England. Based on the Earl's disbursement books in the estate office at Chatsworth House, it does much to illuminate the lifestyle and interests of a man, who until now has remained largely in the shadow of his more famous mother, Bess of Hardwick. No book-length biography of him has yet been published, a surprising omission given that by his death, Cavendish had built up one of the greatest estates of the seventeenth century. This book goes some way to filling that gap, and it builds firmly on the author's equine expertise from his earlier monographs: The Horse Trade of Tudor and Stuart England (Cambridge, 1988), and Horse and Man in Early Modern England (London, 2007).

The research outlines contemporary theory and practice behind the breeding, rearing, care, treatment and trading of horses, with the high quality stud established by the Earl at Hardwick as its case study. It demonstrates the considerable expense to maintain this facility, from paying a stable staff of up to 40 servants, to the costly treatments for those horses prone to ailments. Yet the book makes a broader contribution than just equine history; it offers much to interest agricultural historians and scholars of material culture. Beyond horse-breeding, Edwards details Cavendish's many and varied seigneurial, agrarian, industrial and commercial interests, from farming his demesne, to lead-smelting and investing in the emerging overseas trading companies of his day. Themes such as landlord-tenant relations, travel, luxury goods, noble 
pastimes and hospitality feature strongly. Much of the book is devoted to describing Cavendish's household and estate management, concluding the Earl was a 'very astute manager of his finances', but that breeding fine horses such as the coveted Spanish Ginete stallions was vastly more expensive than other forms of livestock rearing.

The book covers much ground, but there are moments where the reader is left hungry for more. Cavendish established Langwith Park as a paled deer park from 1600, but Edwards considers him a 'lukewarm huntsman' who 'primarily used the park as an outdoor larder.' The cultural significance of hunting deer (an animal linked to royalty), to inculcate martial valour is left underplayed, whilst Cavendish's intriguing Star Chamber suit of 1608-9 against Sir Percival Willoughby for hunting in Langwith Park is mentioned but not explored in detail. There is a helpful map of Cavendish's extensive estates in the north Midlands, but provision of a family tree would have aided the reader, given the Earl's complicated kinship network. Edwards places Cavendish in his contemporary context by comparing him to his peers such as the fifth and sixth Earls of Rutland, but makes the startling claim that Cavendish was 'never really interested in politics or politicking', and that office-holding was a distraction for him from his principal concern of estate management. Yet for the second son of a Derbyshire knight to have amassed one of the greatest estates in seventeenth-century England, was surely a substantial political achievement. He also successfully defended his mother in a feud with his step-father, George Talbot, sixth Earl of Shrewsbury. He proved adept at defending his inheritances at law. Although he was no aspiring courtier, the Earl became a frequent attender in the House of Lords and often spent two thirds of his year in London. Indeed the Earl's lifestyle, engagements and accumulation of property in London are ably outlined at length. Above all, the book encapsulates very well how clearly Cavendish understood the cultural value of fine horses and the importance 
of their display in the very status-conscious world he inhabited. For as Edwards himself reminds us, the mastery of a fine horse was a 'powerful metaphor for governance'.

ANDREW HOPPER

University of Leicester 